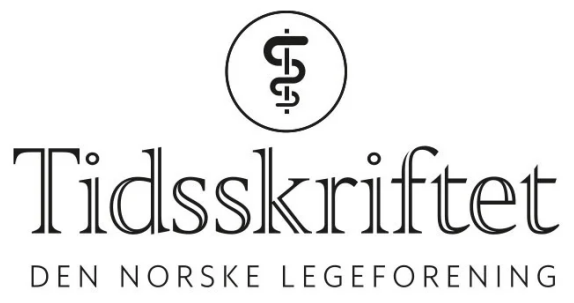

\title{
God kommunikasjon kan læres
}

NYHETER

\section{ANNE FORUS}

Email:anne.forus@hotmail.com

Tidsskriftet

Et 20-timers kurs som lærer leger fire gode vaner for god klinisk kommunikasjon bedrer kommunikasjonsferdighetene. Kurset anbefales for alle sykehusleger. 


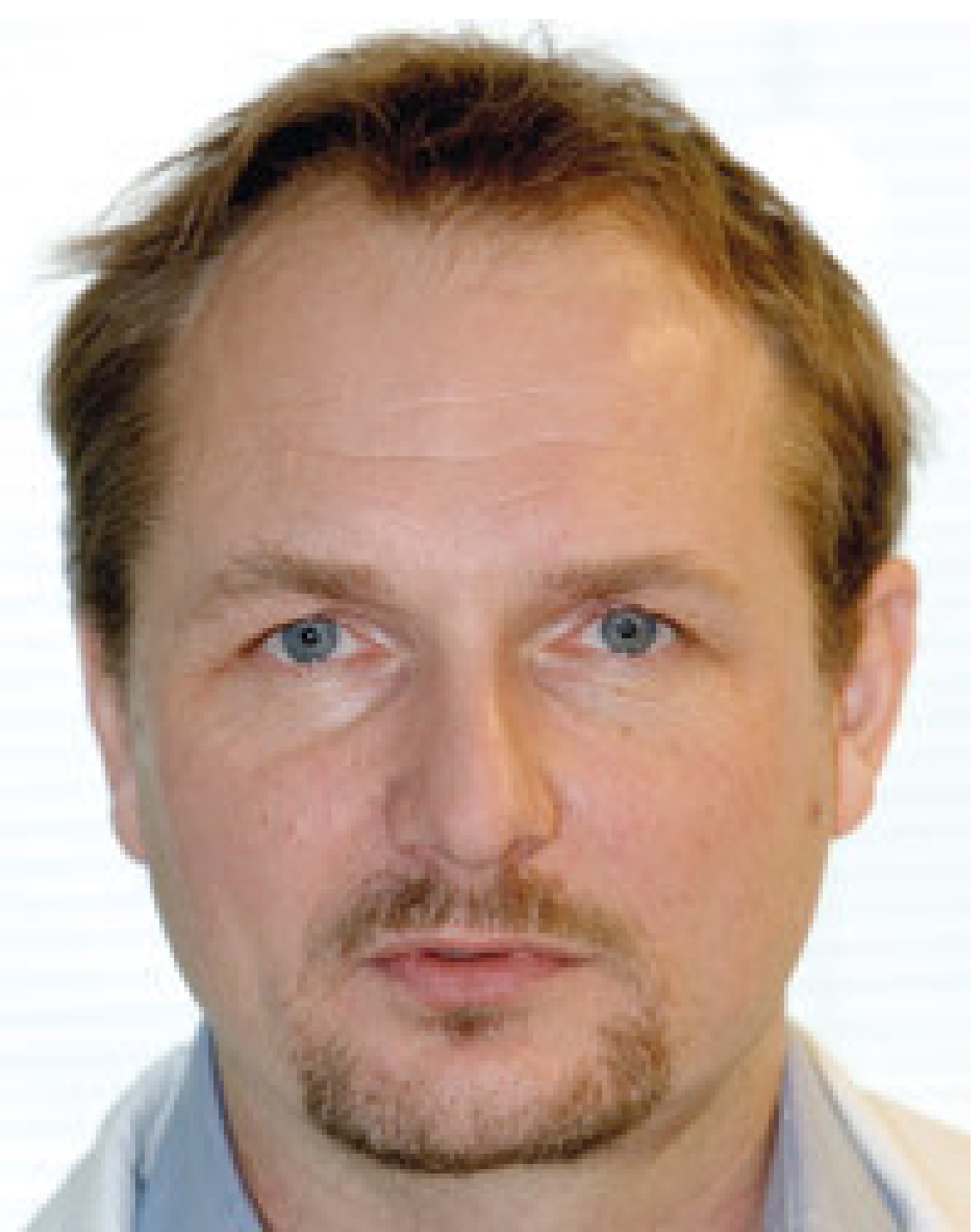

Bård Fossli Jensen. Foto Geir Boye Lundhjem, Akershus universitetssykehus

Prinsippene for god kommunikasjon mellom lege og pasient er velkjente, men det finnes ingen større studier der man har sett på effekten av kommunikasjonstrening for sykehusleger generelt. Bård Fossli Jensens egen erfaring fra et kommunikasjonskurs vakte interessen for å studere dette nærmere.

- Jeg deltok på trening etter modellen «Fire gode vaner for klinisk kommunikasjon». Kurset ble en aha-opplevelse, sier Fossli Jensen. - Jeg kjenner meg mer profesjonell og ser ikke bort fra at jeg også er blitt en bedre lege.

Grunnprinsippene i god kommunikasjon er å skape en trygg atmosfære, vise interesse for pasientens perspektiv, vise medfølelse og gi informasjon på en effektiv måte. Sykehusleger ved Akershus universitetssykehus ble kurset i dette. Legene ble filmet før og etter trening, totalt åtte ganger i løpet av ett år. Over 500 møter mellom leger og pasienter ble filmet.

- Legenes utgangsskårer lå under midten på skalaen, hvilket kan tyde på et ikke ubetydelig forbedringspotensial. Den gode nyheten er at treningen ga signifikant bedring, sier Fossli Jensen.

De fleste av pasientene som ble spurt (94\%), sa ja til å bli filmet. 
- Pasientene var overveldende positive. De ga klart uttrykk for hvor viktig det er at vi legger vekt på legers kommunikasjonsferdigheter, sier han.

I tillegg til filmingen vurderte pasientene legenes kommunikasjon ved hjelp av spørreskjemaer. Dette viste seg å være lite nøyaktig.

- Det har lite for seg å prøve å identifisere leger som har dårlige kommunikasjonsevner ved hjelp av spørreskjemaer, det blir altfor unøyaktig. Når vi i tillegg ser at vi alle har noe å lære, er det bedre å tilby trening til samtlige, sier han.

\section{Disputas}

Bård Fossli Jensen disputerte for graden ph.d. ved Universitetet i Oslo 7.10. 2011. Tittelen på avhandlingen er Hospital doctors' communication skills. A randomized controlled trial investigating the effect of a short course and the usefulness of a patient questionnaire.

Publisert: 13. desember 2011. Tidsskr Nor Legeforen. DOI: 10.4045/tidsskr.11.1231

(C) Tidsskrift for Den norske legeforening 2023. Lastet ned fra tidsskriftet.no 26. april 2023. 